\title{
Secondary Metabolites from Mimosa Pudica: Isolation, Purification and NMR Characterization
}

\author{
Ahamefula Anselm Ahuchaogu ${ }^{1}$ Okoronkwo Joseph Chukwu ${ }^{1}$ and \\ JohnBull Onyekachi Echeme ${ }^{1}$. \\ ${ }^{I}$ Department of Chemistry, Michael Okpara University of Agriculture, Umudike, Umuahia, Abia State, Nigeria.
}

\begin{abstract}
Aim: isolation, purification and NMR characterization of secondary metabolites in Mimosa pudica. Study design: extraction, isolation and identification of the secondary metabolties from the petroleum ether and metabolites extracts from Mimosa pudica.

Methodology: In the course of our study on Mimosa pudica, a compound was isolated and purified using different chromatographic techniques and the structure of the compound determined on the basis of their spectroscopic data (IR, HNMR, COSY, DEPT, MS).

Place and Duration of Study: this work was carried out in the chemistry Department Michael Okpara University of Agriculture, Umudike, Abia State, Nigeria within the month June 2016 to December 2016.

Result: The entire plant parts of Mimosa was extracted using absolute ethanol, the TLC of the crude extract indicate the many compounds with $R f$ values $0.41,0.43,0.56,0.68,0.89$ and 0.90 . Purification: The results of several chromatographic techniques on the isolated gave rise to a triterpenoid-glycoside with $R f$ value 0.55 . The spectral analyses involving HNMR, NMR, DEPT, ${ }^{135}$ COSY, HMBC and IR, MS were useful in proposing the structure of the compound MP11.
\end{abstract}

Keywords: Mimosa pudica, Mimosine, secondary metabolites, chromatography, characterization.

\section{Introduction}

According to World Health Organization (W.H.O), more than $80 \%$ of the world's population relies on traditional medicine for their primary health-care needs. Use of herbal medicines in Asia represents a long history of human interactions with the environment. Plants used in traditional medicine contain a wide range of ingredient that can be used to treat chronic as well as infectious diseases. Several screening studies have been carried out in different parts of the world (Jina et al., 2005).

There are several reports of the antimicrobial activity of different herbal extracts in different regions of the world. Because of the side effects and the resistance that pathogenic micro-organisms build against conventional antibiotics. Recently much attention has been paid to extracts and biologically active compounds isolated from different plant species used in herbal medicine (Jina et al., 2005).

Mimosa pudica Linn is a creeping annual or perennial herb often grown for its curiosity value, as the compound leaves fold inward and drop when touched and reopens within minutes. The generic name Mimosa is derived from the Greek mimos (meaning mimic) alluding to the fact that the leaves moves in response to something moving against them. The specific epithet is taken from the Latin word pudica, meaning bashful or shrinking to contact (Barneby, 1991). Mimosa is a genus of about 400 species of herbs and shrubs, in the subfamily mimosoideae of the Legume family Fabaceae.The plant is native to Brazil, but is now a pan tropical weed, The species is known by numerous common name including

I. Sensitive plant

II. Humble plant

III. Shameful plant

IV. Touch-me-not

V. Chuimui

VI. Ant-plant

\section{Vernacular- names:}

Non-English common names in three major languages in Nigeria, European language, culture areas include;

Igbo Language: Agbogho mechie ukwu.

Hausa Language: Kama walkinka.

Yoruba Language: Ewe padimo/ Patomo

In European language/ culture areas we have nao- me- toque (touch- me- not), sensitive or dormideira (roughly sleeper") in the Portuguese (with the former being more common in Portugal. Africa and Rio, dejaneiro, the middle in Sao Paulo city and the Southern capitals and the latter elsewhere in Brazil), while in 
Spanish, it varies in names such as mori- vivi or morivivi (DOMINICAN REPUBLIC, PUERTO RICO and other Spanish- speaking Caribbean islands, roughly translating to "I died, I lived") (Union county College Biology Department, 2008) and Dormilona (Costa Rica).

In Austronesia names vary more: in the philippines it is called makahiya, with maka-meaning "quite" or tendency to be", and -hiya meaning "shy" or "shyness",while in Tonga for example it is known as Mateloi (false death) (Churchward, 1959), being Putri- malu (shy princess) in Indonesia and Pokok Semalu (shy plant), in Malaysia. In Sinhala (Sri Lanka) it is called Nidi kumba (sleeping plant).

In south Asia many unrelated names are also common. In Hindi it is known as chhui-mui (that which dies upon touch). In Bengali, the shrub is called lojjaboti ("that bashful girl"). In Malayalam it is called thottavaadi ("wilts by touch). In marathi it is called lazalu ("shy").In Tamil, it is called thottasiningi ("acts when touched") and in kannada, it is known as muttidare muni ("angered by touch"). In Burmese (Myanmar) it is called hti ka yoan, which means "(crumbles when touched)". In Liberia, it is known as the picker weed (Union county College Biology Department, 2008).

This plant has a history of use for treatment of various ailments and the most commonly used plant part for this purpose is the root; but flowers, back and fruit can also be utilized. Several research works have been carried out to study about the phytochemical components of Mimosa pudica and also about the antimicrobial activity of the plant (Gandhiraja et al., 2009). Phytochemical studies on $M$. pudica have revealed the presence of alkaloids, fatty acids, non-protein amino acid (mimosine), flavonoids, C-glycosides, sterols, terpenoids, and tannins (Genest et al., 2008). Reported major pharmacological activities are; antiviral properties, aphrodisiac properties, antimicrobial properties, anti-venom activities, anti-hepatotoxic and antioxidant effects, diuretic effect, hyperglycemic effect, wound healing effect etc. (Amalraj and Ignacimuthu, 2002). Some of the isolated secondary metabolites are bufadienolide, D-pinitol, norepinephrine, P-coumaric acid, mimopudine, mimosine, potassium-5-O- $\beta$-gluco-(Clark-Lewis and Porter, 1972).pyranosygentisate etc. (Yadava and Yadav, 2001), (Ueda et al., 2000), (Sallaud et al., 1995), (Fromm and Lautner, 2007; Nair et al., 2007 and Genest $e t$ al., 1999). Two well-known movements are observed in M. pudica: one is the very rapid movement of the leaves when it is stimulated by touch, heat etc, and the other is the very slow, periodical movement of the leaves called nyctinastic movement which is controlled by a biological clock (Ueda et al., 1999) .

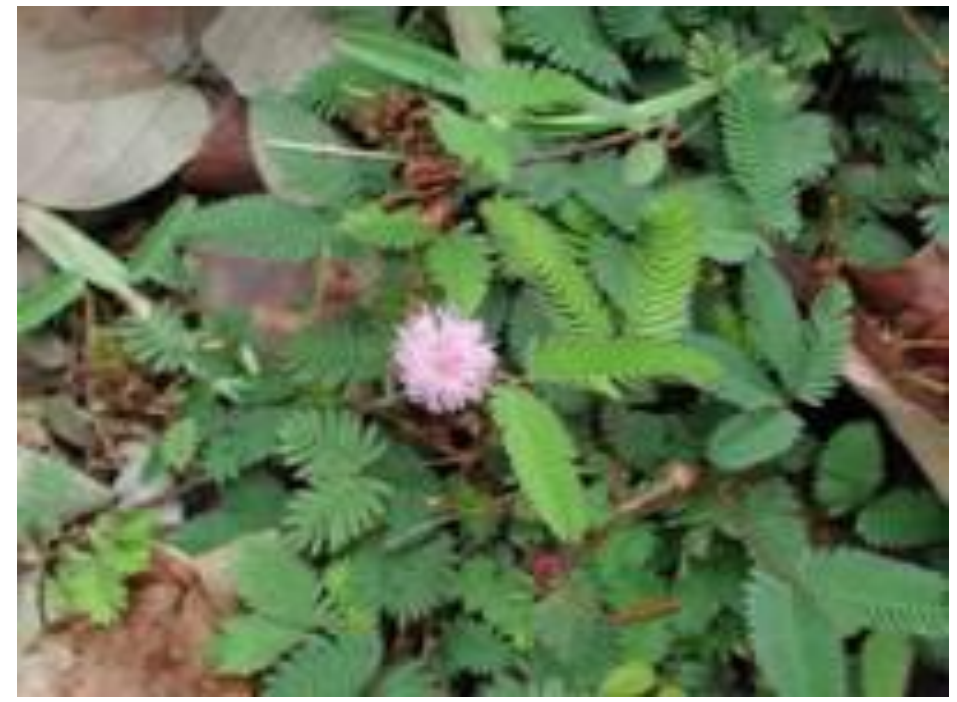

Mimosa pudica leaves and flowers

\section{Sample collection and preparation:}

\section{Materials and Methods}

Fresh and wholesome parts of Mimosa pudica were collected during the month of August 2014, from Ndi-Ojigwe compound in Okoko Item,Bende Local Government Area of Abia State,Nigeria. The plant was identified and authenticated by Mr. I. Ndukwe in plant taxonomy section, forestry Department of Michael Okpara University of Agriculture Umudike, Nigeria. The fresh plant materials were dried under shade to prevent interference of uv-radiation from the sun. Dried plant materials were powdered using Mechanical grinder. Then the powdered material was preserved in an air tight container; ready for extraction. 


\section{Extraction and Isolation of Plant Material:}

$2 \mathrm{~kg}$ of the milled sample was percolated in $98 \%$ ethanol for 48 hours. Thereafter, it was filtered through Whatman Filter Paper (No 42). The filtrate was concentrated using the Digital Heidolph Rotaryevaporator (4000 series) at crude extract $\left(48.9 \mathrm{~g}\right.$ ). the crude extract was partitioned between $\mathrm{CHCl}_{3}$ and water and a $\mathrm{CHCl}_{3}$ - soluble fraction (16.3g) was obtained. $10.0 \mathrm{~g}$ of the $\mathrm{CHCl}_{3}$ fraction was then partitioned between petroleum ether $\left(60-80^{\circ} \mathrm{C}\right)$ and aqueous methanol. 5.0g of the $\mathrm{CHCl}_{3}$ fraction was then subjected to column chromatography over silica gel (200 mesh) and eluted gradually with $100 \mathrm{ml}$ petroleum ether, then petroleum ether: $\mathrm{CHCl}_{3}(95: 5 ; 90: 10 ; 85: 15 ; 80: 20 ; 75: 25 ; 70: 30 ; 65: 35 ; 60: 40 ; 55: 45 ; 50: 50 ; 40: 60 ; 30: 70 ; 20: 80 ; 10: 90)$, and $100 \mathrm{ml} \mathrm{CHCl}_{3}$. Then $\mathrm{CHCl}_{3}$ : Methanol $(90: 01 ; 80: 20 ; 70: 30 ; 60: 40 ; 50: 50 ; 40: 60 ; 30: 70 ; 20: 80 ; 10: 90)$ and $100 \mathrm{ml}$ methanol, followed by methanol: Ethyl acetate $(80: 20 ; 60: 40 ; 40: 60 ; 20: 80)$ and $100 \mathrm{ml}$ Ethyl acetate to yield twelve major fractions. Chromatographic (partition chromatography, column chromatography and TLC) and spectroscopic $\left({ }^{1} \mathrm{H}-\mathrm{NMR},{ }^{13} \mathrm{CNMR}, \mathrm{COSY}\right.$, DEPT, HMBC, HMQC, IR) techniques were employed to isolate, purify, characterize and identify active constituents from $\mathrm{CHCl}_{3}$ extracts of the sample.

\section{Results and Discussion}

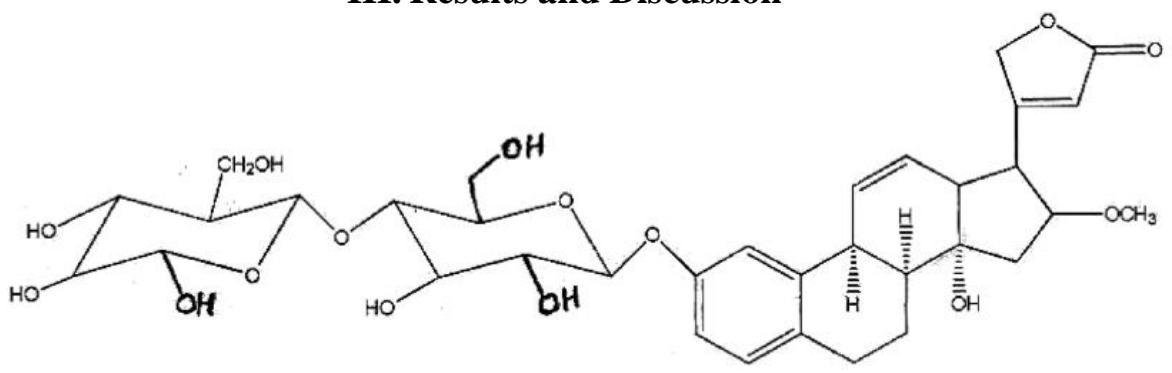

Fig 1: Structure of MP-11

Compound [1] labelled MP-11 was eluted with chloroform and petroleum ether at the ratio of 60:40. Thin layer chromatography carried on MP-11 showed one spot $\left(\mathrm{R}_{\mathrm{F}} 0.55\right)$. Analysis of IR is shown in Table 1 . The IR revealed Vmax $2980 \mathrm{~cm}^{-1}, 1700 \mathrm{~cm}^{-1}, 1600 \mathrm{~cm}-1$ and $1250 \mathrm{~cm}^{-1}$ for aliphatic, carbonyl, olefinic, aromatic and ether respectively. Analysis of ${ }^{1} \mathrm{H}-\mathrm{NMR}$ revealed the presence of olefinic protons at ${ }^{\mathrm{H}} \mathrm{H}$ 5.20, cluster of peaks between $\precsim \mathrm{H} 0.8$ to $\jmath_{\mathrm{H} 2} .35$ clearly indicated the triterpenoid structure, and three proton singlet at $\jmath^{\mathrm{H}} 3.5$ indicates the presence of a methoxy group in the molecule. Then the presence of two anomeric protons at ${ }_{\mathrm{H}} \mathrm{H} 5.45$ and ${ }_{\mathrm{H}} \mathrm{H} 5.25$ confirmed the presence of two sugars.

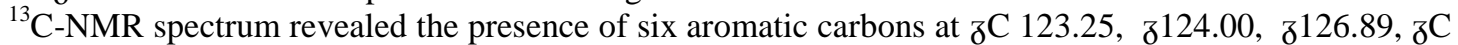
$127.01, \jmath^{C} 129.04$ and $\jmath^{C} 133.88$. Methylene carbons chemical shift were seen at $\jmath^{C} 21.60-8 \mathrm{C} 22.41$, methane carbon peaks were observed at $\mathrm{C} \jmath^{26.96}$ to $\jmath_{\mathrm{C}} 33.39$, while the signal at $\jmath_{\mathrm{C}} 172.93$ indicates the presence of carbonyl carbon, which is an integral part of the triterpenoid. Based on the chromatographic data, IR, NMR, COSY, DEPT, HMBC and HMQC, the structure of MP-11 was proposed as shown in figure [1] with molecular formula $\mathrm{C}_{34} \mathrm{H}_{44} \mathrm{O}_{5}$ which is a triterpenoid-glycoside.

Table 1: Infra-red Analysis of MP-11

\begin{tabular}{|l|l|l|}
\hline IR Absorption $\left(\mathbf{c m}^{-1}\right)$ & Functional Group & Compound Type \\
\hline 2980 & $-\mathrm{CH}_{2}$ & Aliphatic \\
1700 & $\mathrm{C}=\mathrm{O}$ & Carbonyl \\
1670 & $\mathrm{C}=\mathrm{C}$ & Olefin \\
1600 & $\mathrm{C}=\mathrm{C}$ & Aromatic \\
1250 & $\mathrm{C}-\mathrm{O}$ & Ether \\
\hline
\end{tabular}

\section{Conclusion}

The result of this analysis revealed that the plant Mimosa pudica has many of its secondary metabolites responsible for its numerous biological activities yet to be isolated and documented. Thus the isolated compound contributes to the scientific evidence for the use of this plant in traditional medicine for the treatment of diseases in Nigeria

\section{References}

[1]. Ammara, H., Salma, R., Farah, D.and Shahid, M. (2009). Antimicrobial activity of some plant extracts having hepatoprotective effects. J. med. Plants Res. 3(1); 020-023

[2]. Ahmad, H., Seggal, S., Mishra, A., Rajiv, G. (1975). Mimosa pudica L (Laajvanti). An overview; pp 1-15.

[3]. Applewhite, P. (1973). Phytochemistry pp.191

[4]. Anderson, W. A. and Freeman, R. (1962). "Influence of a Second Radio Frequency Field on High-Resolution Nuclear Magnetic Resonance Spectra". The Journal of Chemical Physics 37(1):411-5. 
[5]. AOAC (1990). Association of Official Analytical Chemists $15^{\text {th }}$ ed. Washington D.C.

[6]. Anonymous (2000). Compendium of pharmaceuticals and specialties, $25^{\text {th }}$ ed. Canadian pharmacist Association, Toronto, Canada.

[7]. Azhari, H., Muhammad, K., Ahmad Ziad, S., Tahira, B., Abdurahman, H.,Muhammad, K². Faridah, K. (2014). In vitro anti acetyl cholinesterase and antioxidant activity of selected Malaysian plants. Asian Journal of Pharmaceutical and Research. Vol. 7. Pp. 9396.

[8]. Agharkar, S.P. (1991). Medicinal plants of Bombay presidency. Pbl. Scientific publisher, jodhpur, India. Pp.142-143.

[9]. Amalraj, T. and Ignacimuthu, S. (2002). Hyperglycemic effect of leaves of Mimosa pudica Linn. Fitoterapia. 73: 351-2.

[10]. Anton, R., Jiang, Y., Weniger, B., Becker, J. P. and Rivier, L. (1993), Pharmacognosy of Mimosa tenuiflora (Willd.) Poiret. J. Ethnopharmacol. , 38, 153-157.

[11]. Adebisi, A.and Bosch, C. (2004). Lablab purpureus (L). sweet. In: Grubben GJH, Denton OA. (eds.) plant Resources of Tropical Africa (TROTA), no. 2. The Netherlands, pp 343-348.

[12]. Bunning, E. (1973). The Physiological Clock, Third Edition, English Univ. press: London

[13]. Barneby, R. (1991). Sensitive censitae: a description of the genus Mimosa Linnaeus (Mimosaceae) in the New World. New York Botanical Garden, New York.

[14]. Behera, S.K, Panda, A., Behera, S.K. and Misra, M.k. (2006). Medicinal plants used by the Kandhas of Kandhmal District of Orissa. India J. Tradition Knowl. 5:519-28

[15]. Bum, E., Dawack, D., Schmutz, M., Rakotonirina, S. and Portet, C. (2004). Anticonvulsant activity of Mimosa pudica decoction. Fitoterapia. 75:309.

[16]. Burkill, H. (1995). The useful plants of West Tropical Africa, Vol. 3, J-L Royal Botanic Gardens, Kew. pp.56.

[17]. Bisby, H., Buckingham, J. and Harborne, J. (1994). Phytochemical Dictionary of the Leguminosae. ILDIS. Chapman \& Hall, London.

[18]. Bohm, B. A. and Kocipal- Abyazan, R. (1994). Flavonoid and condensed tannins from leaves of Vaccicum raticulation and Vacinum calcyimium. Pacific Science. 48: 458-463.

[19]. Banso, A. (2009). Phytochemical and antibacterial investigation of bark extracts of Acacia nilotica. J. Med. Plants Res., 3(2): 082085 .

[20]. Brenner, G.M. (2000). Pharmacology. W.B. Sounders Company, Philadelphia

[21]. Bendgude, R.D., Maniyar, M.G., Kondawar, M.S., Patil, S.B., Hirave, R.V. (2012).

[22]. Anthelmintic Activity of leaves of mimosa pudica. International journal of Institutional pharmacy and life sciences.2(1).

[23]. Brown, G.K., Murphy, D.J., Miller, and P J.T.and Ladiges, Y. (2008). Acacia s.s.and its relationship among tropical legumes, Tribe Ingeae (Leguminosae: Mimosoideae). Syst. Bot., 33: 739-751.

[24]. Bodenhausen, G., Ruben, D. J. (1980). Natural abundance Nitrogen-15 NMR by enhanced heteronuclear Spectroscopy,chemical physics letters 69(1): 185-189.

[25]. Cheeke, P. R. (1971). Nutritional and Physiological Implications of Saponins.A review Can .J. Anim . Sci. 51: 621-632.

[26]. Churchward, C.M. (1959). Tongan Dictionary. Tonga: Government Printing press. P. 344.

[27]. Chauhan, B., Johnson, S.and Davi, E. (2009)."Germination, emergence, and dormancy of Mimosa Pudica". Weed Biology and management 9(1): 38-45. Doi:10. 1111/j.1445-6664. 2008.00316.x.

[28]. Chatterjee, A. and Pakrashi, S. (2006). The treatise on Indian medicinal plants. New Delhi: national Institute of science Commission and information Resources; Pp. 65-6.

[29]. Chowdhury, S.A. (2008). Cytotoxicity, Antimicrobial and Antioxidant studies of different plant parts of mimosa pudica. Stamford journal of pharmaceutical sciences. 1(1,2): 80-84.

[30]. Cook, B., Pengelly, B., Brown, S., Donnelly, J., Eagles, D., Franco, M., Hanson, J., Mullen, B., Partridge, I., Peters, M.and Schultzekraft, R. (2005). Tropical Forages: an interactive selection tool [CD-ROM]; CSIRO, CIAT and ILRI, Brisbane, Australia. pp. 30-80.

[31]. Carver, T. R.and Slichter, C. P. (1953). "Polarization of Nuclear spins in metals". Physical Review 92(1):212-213.

[32]. Corthout, J., Pieters, L.A., Claeys, M., Vanden Berghe, D.A. and Viletink, A. J. (1994). Anti-viral caffeoyl esters from Spondias mombin. Planta Medica. 60: 460-463.

[33]. Cowan, R.A. (1998). Mimosaceae (excl. Acacia), Caesalpiniaceae. Flora of Australia. 12 (ABRS/CSIRO Publishing).

[34]. Camargo-Ricalde, S. L. (2000), Descripción, distribución, anatomía, composición química y usos de Mimosa tenuiflora (FabaceaeMimosoideae) en México Revista Biologica Tropical, 48, 939-954.

[35]. Du Fay, (Paris 1729). Observation Botanique. Histoire de L' Academic Royale des Science P 35.

[36]. Darwin, C. (1880). The power of movement in plants, John Murray: London. Pp. 695-710.

[37]. Derome, A.E. (1987). Modern NMR techniques for chemistry Research, pergamon press. New York. P. xvi

[38]. Edeoga, H. O., Omosun, G. and Uche, L. C. (2006). Chemical Composition of Hyptis Suaveolens and Ocimum gratissimum hybrids from Nigeria. Afr. J. Biotech., 5(10): $892-895$.

[39]. Elmerich, C. and Newton, W. E. (2007). Associative and endophytic nitrogen- fixing bacteria and cyanobacterial associations. Springer. P. 30. ISBN 978-1-4020-3541-8.

[40]. Elias, T.S. (1981). Mimosoideae, In: Advances in Legume Systematics. (Eds.): R.M. Polhill and P.H. Raven. Part 1. Royal Botanic Gardens, Kew, London. pp. 143-151.

[41]. Englert et al, (1995). Triterpenoid Saponics from mimosa Pigra .J. Nat. Prod. 58.P. 1265-1269.

[42]. Fromm, et al., (2007). Electrical signal and their physiological significance in plants. Plant cell \& Environment. http://onlinelibrary.wiley.com/doi/10.1111/y.1365-3040.2006.01614.x/pdf.

[43]. Genest, S., Kerr, C., Shah, A., Rahman, M.M., saif-E-Nasar, G.M., Nigam, P, et al. (2008). Comparative Bioactivity of two Mimosa Species. Lat Am Caribb Bull med Aromat plants. 7:38-43.

[44]. Groves, R., Boden, R., Lonsdale, W. (2005). Jumping the garden fence: Invasive garden plants in Australia and their environmental and agricultural impacts. CSIRO report prepared for WWF-Australia. WWF-Australia, Sydney. Pp173

[45]. Gandhiraja, N., Sriram, S., Meenna, V., Kavitha Srilakshmi, J., Sasikumar, C., Rajeswari, R. (2009). Phytochemical Screening and Antimicrobial Activity of the plant Extracts of Mimosa Pudica. L. Against Selected Microbes. Ethnobotanical leaflets, 13:618-24

[46]. Gareth, A. M. and Ray, F. (1979). "Enhancement of Nuclear Magnetic Resonance Signals by Polarization Transfer". Journal of American Chemical Society. 101(3): 760-762.

[47]. Goh, K.W. and Smith, R.F. (1985). Pesticides safety for IPM field counts. Chemical pesticides programme. Cornel University Ithaca New York.

[48]. Ganguly, M., Devi, N., Mahanta, R., Borthakur, M.K. (2007). Effect of Mimosa pudica root extract on vaginal estrous serum hormones for screening of antifertility in albino mice. EPUB. 76(6): 482-5.

[49]. Howard, J. (2002). Get Cholinestrase Test Now. 48824-1323. 
[50]. Harbone, J.B. (1973). Phytochemical methods. A guide to modern techniques of plant analysis Chapman and Hall, London, 279.

[51]. Ihekoronye, A. I. and Ngoddy, P. O. (1985). Integrated Food Science and Technology for the Tropics. Macmillan Educational Ltd. Pak. J. Nutr. 7(1): 130-132.

[52]. Iwu, M. (1993). Handbook of African Medicinal Plants. CRC Press, Boca Raton, Florida.

[53]. IUCN Red list of threatened species (2006). Mimosa Verrucosa.

[54]. Jina, P., Darshana, J. and Sumitra C. (2005). Efficacy of aqeous and Methanol extracts of some medicinal plants for potential Antibacterial Activity. Turk. J. Biol 29:203-210.

[55]. Journal of Natural products: Vol. 42, Issue 2 (ACS Publication” pubs.3. acws. Org. Retrieved 2008-05-07

[56]. Jiang, Y. L., Massiot, G., Lavaud, C., Teulon, J. M., Guechot, C., Haag-Berrurier, M. and Anton, R. (1991a), Triterpenoid glycosides from the bark of Mimosa tenuiflora. Phytochemistry, 30, 2357-2360.

[57]. Jiang, Y. L., Weniger, B., Haag-Berrurier, M., Anton, R., Beck, J. P. and Italiano, L. (1992), Effects of Saponins from Mimosa tenuiflora on Lymphoma Cells and Lymphocytes.Phytoter Res, 6, 310-313.

[58]. Just, M. J., Recio, M. G., Giner, R. M., Cueller, M. J., Manez, S., Bilia, A. R. and Rios, J. L. (1998). Anti-inflammatory activity of unusual hipine Saponins from Bupleurum Fruticescens. Planta Mech., 64: 404-407.

[59]. Kozikowski, A. and Tucmental, W. (2000). Chemistry, pharmacology and clinical efficacy of the Chinese Nootropic Agent Huperzin A Luckow, India.

[60]. Khopkar, S. M. (2008). Basic Concepts of Analytical Chemistry. New Age International publishers.New Delhi. $3^{\text {rd }}$ ed. Pp. $450-457$.

[61]. Kannan, S., Aravinth, V.J.S., Sam, J.K.E., Sammathan, J., Suthakaran, R., Kumar, R., Mand Parimala, D.B. (2009). Wound healing activity of Mimosa pudica Linn formulation. IJPR; 1(4): 1554-58.

[62]. Kam, P. C. A and Liew, S. (2002). Traditional Chinese herbal medicine and anesthesia. Anaesthesia, 57; 108

[63]. Knekt, P., Jarvinen, R., Reunanen, A. and Maatela, J. (1996). Flavonoid intake and coronary mortality in Finland: A Cohort Study Biomed. J., 312: 478 - 481. 3-1089.

[64]. Lonsdale, W.M. (1998). "Litter fall in an Australian Population of mimosa pigra, an invasive tropical shrub". Journal of Tropical Ecology 4(4): 381-392.

[65]. Molina, M., Contreras, C., Tellez, A. (1999). Mimosa pudica may possess antidepressant actions in the rat. Phytomedicine. P.319

[66]. Mahanta, M. and Mukherjee, A. (2001). Neutralization of lethality, myotoxicity andtoxic enzymes of Naja kaouthia venom by Mimosa pudica root extracts. J Ethnopharmacol. Pp.55-60

[67]. Maslin, B., Miller, J. and Seigler, D. (2003). Overview of the generic status of Acacia (Leguminosae: Mimosoideae). Austral. Syst. Bot.,16: 1-18.

[68]. Melzer, D. (1998). New drug treatment for Alzheimer's disease: lesson's for healthcare policy Bristisli medical. A Journal, 316, 762-764.

[69]. Morrison, R.T. and Boyd, R.N. (2008). Organic Chemistry. $6^{\text {th }}$ ed. Prentice Hall of India., New Delhi, pp $586-665$.

[70]. Mabberley, D.J. (2008). Mabberley's Plant-Book.: A portable dictionary of plants, their classification and uses. Third edition, Cambridge University Press.: 7-18: 1-1021.

[71]. Meenatchisundaram, S., Priyagrace, S., Vijayaraghavan, R., Velmurugan, A., Parameswari, G., Michael, A. (2009). Antiflammatory activity of Ethanolic extract of mimosa pudica Linn leaves. Journal of Biomedical and pharmaceutical. 1(1): 36-28.

[72]. Maxwell, A., Seepersand, M., Pingal, R., Mootoo, D. R. and Reynolds, W. F. (1995). 3-beta-amino spirosolane steroidal, alkaloids from Solanium triste .J. Natl. Proda, 58: $625-628$.

[73]. Muthukumaran, P., Pattabiraman, K., Kalaiyarasan, P. (2010). Hepatoprotective and antioxidant, activity of mimosa pudica on carbon tetrachloride-induced hepatic damage in rats. International journal of current Research; 10:46-53.

[74]. Malinow, M. R., Mclaughin, P., Kohler, G. O. and Livingstone, A. L. (1977a) Alfalfa Saponinis: A family of substance potentially useful for treatment of hypercholesterolaemia Clin. Res 25: 974-979.

[75]. Malinow, M. R., Mclaughin, P., Kohler, G. O., Living Stone, A. L. (1977b). Prevention of elevated cholesterolaemia in monkeys. Steroids, 29:105-110.

[76]. Middleton, E. and Kandswani, H. (1992). Effects of flavonoids on immune and inflammatory functions, biochemistry and pharmacology, 43, 1167-1172.

[77]. Meckes-Lozoya, M., Lozoya, X., Marles, R., Soucy-Breau, C. and Avalokitesvarasen, A.J. (1990a), N,N-Dimethyltryptamine alkaloid in Mimosa tenuiflora bark (Tepescohuite). Archivos de Investigación Medica, 21, 175-177.

[78]. Ngo Bum, E., Dawack, D.L., Schmutz, M., Rakotonirina, A., Rakotonirina, S.V., Portet, C., Jeker, A., Olpe, H.R., Herrling, P. (2004). Anticonvulsant activity of mimosa pudica decoction. Fitoterapia,75 (3-4): 309-14.

[79]. Nobori, T., Miurak, K., Wu, D. J., Takabayashik, L. A. and Carson, D. A. (1994). Deletion of the cyclin-dependent Kinase - 4 Inhibitor gene in multiple human cancers. Nature; 368 (6473): 753-756.

[80]. Nazeema, T.and Brindha, V. (2009). Antihepatotoxic and antioxidant defense potential of Mimosa pudica. Int J Drug Disc. pp.1-4 Tsurumi, S. and Asahi, Y. (2006). Identification of jasmonic acid in Mimosa pudica and its inhibitory effect on auxin-and lightinduced opening of the Pulvinules. Physiologia plantarum; 64:pp.207.

[81]. Trease, G. E. and Evans, W. C. (1989). Textbook of Pharmacognosy, $14^{\text {th }}$ Edition. W. B. Sanders, London.

[82]. Ueda, M. and Yamamura, S. (1999). The chemistry of leaf movement in mimosa Pudica L. Tetrahedron 55:10937-48

[83]. Ueda, M. and Yamamura, S. (2000). Angew. Chem. Int. Engl 39, 1400. Union County College Biology Department (2008). "The Sensitive Plant".

[84]. Vetter, J. (2000). Plant cyanogenic glycosides. Toxicon 38, pp11-36. WHO (2004): Hydrogen cyanide and cyanides: Human Health.

[85]. Virgili, F. and Marino, M. (2008). Regulation of cellular signals from Nutritional molecules, a specific phytochemical, Beyond antioxidant activity: Free biology and Medicine 45(9): 1265-16.

[86]. Vinutha, B., Prashanth, D., Salma, K., Sreeja, S., Pratifi, D., Padmaja, R., Radhika, S., Amit, A., Venkateshwanlu, K., Deepak, M. (2007). Screening of selected Indian medicinal plants for acetyl cholinesterase inhibitory activity. J. Ethnopharmacol .109: 359-363.

[87]. Volkov, A.G. (2008). Pant Electrophysiology in Electrochemical Dictionary. Eds. Bard A.J, Inzelt G, Scholz, F .Springer, Berlin, pp.503-504.

[88]. Weintraub, M. (1951). Leaf movements in Mimosa pudica L. New phytol. pp 357- 382.

[89]. Williams, H.J. (1979). Estimation of hydrogen cyanide released from cassava by Organic.pp. 56

[90]. Wiley, C., Elsa, R., Gerald, S., Tenailleau, E., Akoka, S. (2007). "Precise and accurate quantitative ${ }^{13} \mathrm{C}$ NMR with reduced experiment time". Talanta 71(3): 1016-1021.

[91]. Watson, J. T. (1997). "Introduction to Mass Spectrometry", $3^{\text {rd }}$ Ed., Lippincott Raven.

[92]. Wink, M. (2003). Evolution of secondary metabolites from an ecological and molecular phylogenetic perspective. Phytochemistry. 2003;64(1):3-19. 
[93]. Yuan, k.and Lujl, Y. (2006). Chemical constituents of C-glycosy/flavones from mimosapudica. You xue xue bae. 41:435-8.

[94]. Zanin, J.L.B, de Carvalho B a, Martineli PS, et al. (2012). The genus Caesalpinia L. (Caesalpiniaceae): phytochemical and pharmacological characteristics. Molecules.;17(7):7887-902.

[95]. Nwogu, L.A., and Igwe, C., and Emejulu, A. A. (2008). Effects of Landolphia owariensis leaf extract on the liver function profile and haemoglobin concentration of albino rats, Afr. J. Biotechnol., 2(12): 240-242.

[96]. Nakayoma, J. and Yamada, M. (1995). Suppression of active oxygen - indeed cyto toxicity by Flavonoids. Biochem. Pharmcol., 45:265 - 267.

[97]. Nair, L.S., Menon, S.N., Shailajan, S., Baing, M.M. and Sane, R.T. (2007). Reversed-phase-high-performance-thin-layerchromatographic quantification of mimosine from whole plant of mimosa pudica Linn. J planar Chromatogr. 20: 49-51

[98]. Neumann, U. P., Berg, T., Baha, M., Puhl, G., Guckelbeger, O., Langreh, J. M. and Neuhaus, P. (2004). Long-term outcome of liver transplant for hepatitis C: A 10 year follow-up. Transplantation, 77(2): 226-231.

[99]. Nakamura, E.S., Kurosaki, F and Arisawa M, et al. (2002). Cancer chemopreventive effects of constituents of Caesalpinia ferrea and related compounds. Cancer Lett.;177(2):119-124.

[100]. Obadoni, B.O. and Ochuku, P. O. (2001). Phytochemical studies and comparative efficacy of the crude extract of some homeostatic plants in Edo and Delta states of Nigeria. Global Journal of pure and Applied Science, 86 pp. 2003-2008.

[101]. Olaleye, M. T. (2007). Cytotoxicity and antibacterial activity of methandic extract of Hibiscus Sabadaritta .J. Med. Plants Ros, 1 (1): $009-013$

[102]. Okwu, D. E. (2001). Evaluation of the chemical composition of indigenous species and flavouring agents. Glob. J. Appl. Sci. 7 (3): $455-459$. 